\title{
Photosynthesis and growth of present New Zealand forest trees relate to ancient climates
}

\author{
B.J. Hawkins and G.B. Sweet* \\ School of Forestry, University of Canterbury, Christchurch, New Zealand
}

Seedlings of temperate, northern hemisphere forest tree species have demonstrated optimum growing temperatures which equate closely with climates in which they presently grow (Table I). The species are regarded as recent, many having evolved during the cold Pleistocene climates of the last two million years, replacing species of a much older tropical and subtropical flora (Cox et al., 1976).

Table 1. Temperate, northern hemisphere, forest tree seedlings: a comparison, from the literature, of the differential between optimum growing temperatures and actual summer temperatures, for different species.

\begin{tabular}{|c|c|c|c|}
\hline Species & $\begin{array}{l}\text { Optimum } \\
\text { growing } \\
\text { temp }\left({ }^{\circ} \mathrm{C}\right)\end{array}$ & $\begin{array}{l}\text { Actual } \\
\text { mid-summer } \\
\text { temp }\left({ }^{\circ} \mathrm{C}\right) \text { a }\end{array}$ & Differential \\
\hline 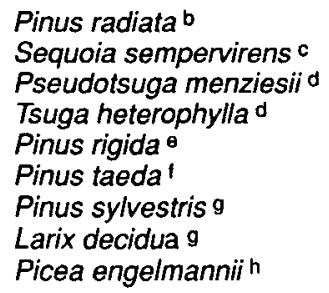 & $\begin{array}{l}23.0 \\
19.0 \\
21.0 \\
18.0 \\
26.0 \\
26.5 \\
17.0 \\
17.0 \\
19.0\end{array}$ & $\begin{array}{l}21.0 \\
17.0 \\
20.2 \\
20.2 \\
27.2 \\
28.3 \\
19.0 \\
19.0 \\
24.1\end{array}$ & $\begin{array}{r}2.0 \\
2.0 \\
0.8 \\
-2.2 \\
-1.2 \\
-1.8 \\
-2.0 \\
-2.0 \\
-5.1\end{array}$ \\
\hline Mean & 20.7 & 21.8 & -1.1 \\
\hline
\end{tabular}

a (Mean temperature of warmest month + mean maximum temperature of warmest month)/2. Climatic data (from meteorological tables) relate specifically to the provenance used in the study.

b Hellmers and Rook (1973), c Hellmers (1966), d Brix (1971), e Good and Good (1976), ' Kramer (1957) 9 Gowin et al. (1980), h Hellmers et al. (1970).

\footnotetext{
* Author to whom correspondence should be addressed.
} 
A series of controlled temperature experiments were carried out with seedlings of 5 species of important New Zealand forest tree genera. Conditions were a $16 \mathrm{~h}$ photoperiod with $10 \mathrm{~h}$ of 'full' light at intensities ranging from 270 to 560 $\mu \mathrm{mol} \cdot \mathrm{m}^{-2} \cdot \mathrm{s}^{-1}$ and a maximum $V P D$ of 12 mbar. The results indicated that all species had an optimum growing temperature of $27^{\circ} \mathrm{C}$ (Table II). In 4 of the 5 species, the net photosynthetic optimum was also at $27^{\circ} \mathrm{C}$, but species differed in whether the main determinant of their increased growth rate at $27^{\circ} \mathrm{C}$ was increased net photosynthetic rate or rate of leaf production (Table III). The New Zealand species in Table $I I$ differed significantly $(P=$
0.0001) from the northern hemisphere species in Table I, in the differential between optimal growing temperature and actual growing season temperature.

New Zealand's forest tree species are ancient and they, or their closest ancestors, have been a dominant element of the country's forest vegetation for the past 50 million years (Fleming, 1975).

The high temperature optimum for the New Zealand species is interpreted as being a physiological 'relic' from the Miocene period, 10-26 million years ago. During that time, temperatures were subtropical, with seas $5-7^{\circ} \mathrm{C}$, warmer than today. That warmth was maintained

Table II. Growth response to temperature for seedlings of New Zealand forest tree species: differential between optimum growing temperatures and actual growing season temperatures.

\begin{tabular}{llll}
\hline Species & $\begin{array}{l}\text { Optimum } \\
\text { growing } \\
\text { temp }\left({ }^{\circ} \mathrm{C}\right)\end{array}$ & $\begin{array}{l}\text { Actual } \\
\text { mid-summer } \\
\text { temp }\left({ }^{\circ} \mathrm{C}\right)\end{array}$ & Differential \\
\hline $\begin{array}{l}\text { Dacrydium cupressinum } \\
\text { Nothofagus solandri var }\end{array}$ & 27.0 & 16.8 & 10.2 \\
$\quad$ cliffortioides & 27.0 & 17.0 & 10.0 \\
Dacrycarpus dacrydioides & 27.0 & 17.9 & 9.1 \\
Podocarpus totara & 27.0 & 21.5 & 5.5 \\
Agathis australis & 27.0 & 22.2 & 4.8 \\
Mean & 27.0 & 19.1 & 7.9 \\
\hline
\end{tabular}

Table III. Growth response to temperature for seedlings of New Zealand forest tree species: percentage increase in growth parameters from $21 / 16$ to $27 / 22^{\circ} \mathrm{C}$ day/night temperatures.

\begin{tabular}{lccc}
\hline Species & Total wt & $\begin{array}{l}\text { Leaf wt/ } \\
\text { total } w t\end{array}$ & $\begin{array}{l}\text { Net } \\
\text { photosynthesis }\end{array}$ \\
\hline $\begin{array}{l}\text { Dacrydium cupressinum } \\
\text { Nothofagus solandri var }\end{array}$ & 41.7 & 30.4 & 2.4 \\
cliffortioides & 22.8 & 38.9 & -29.0 \\
Dacrycarpus dacrydioides & 27.0 & -6.4 & 5.2 \\
Podocarpus totara & 40.0 & 6.0 & 43.6 \\
Agathis australis & 8.3 & 4.7 & 25.9 \\
\hline
\end{tabular}


through the early Pliocene and, 3 million years ago, sea temperatures were still warmer than today (Stevens, 1985).

The fact that 'relic' optimum temperatures for growth have persisted to the present in all species examined, would indicate that there has been little genetic selection for growth rate during the last 3 million years. The authors have data (unpublished) to support the expectation that a major selection pressure exerted by the Pleistocene environment on these subtropical species was for the development of cold resistance.

\section{References}

Brix H. (1971) Growth responses of western hemlock and Douglas fir seedlings to temperature regimes during day and night. Can. J. Bot. 49, 289-294

Cox C.B., Healy I.N. \& Moore P.D. (1976) in: Biogeography, an Ecological and Evolutionary Approach. 2nd edn., Blackwell Scientific Publ., Oxford, pp. 179
Fleming C.A. (1975) The geological history of New Zealand and its biota. In: Biogeography and Ecology in New Zealand. (Kushel G., ed.), W. Junk. The Hague, pp. 1-86

Good R.E. \& Good N.F. (1976) Growth analysis of pitch pine seedlings under three temperature regimes. For. Sci. 22, 445-448

Gowin T., Lourtiox A. \& Mousseau M. (1980) Influence of constant growth temperature upon the productivity and gas exchange of seedlings of Scots pine and European larch. For. Sci. 26, 301-309

Hellmers H. (1966) Growth response of redwood seedlings to thermoperiodism. For. Sci. 12, 277-283

Hellmers H. \& Flook D.A. (1973) Air temperature and growth of radiata pine seedlings. New Zealand J. For. Sci. 3, 271-285

Hellmers H., Genthe M.K. \& Ronco F. (1970) Temperature affects growth and development of Engelmann spruce. For. Sci. 16, 447-452

Kramer P.J. (1957) Some effects of various combinations of day and night temperatures and photoperiod on the height growth of loblolly pine seedlings. For. Sci. 3, 45-53

Stevens G. (1985) In: Lands in Collision Discovering New Zealand's Past Geography. DSIR Informatiorı Series, No. 161 